\title{
Comparative Study Between Direct Steam Generation and Molten Salt Solar Tower Plants in the Climatic Conditions of the Eastern Moroccan Region
}

\author{
Hanane Ait Lahoussine Oualia, Mohammed Amine Moussaouia, \\ Ahmed Mezrhab ${ }^{a^{*}}$, Hassane Najib \\ a Laboratoire de Mécanique et d'Energétique, Faculté des Sciences, Université Mohammed 1, 60000 Oujda, Morocco \\ ${ }^{b}$ Univ. Artois, Univ. Lille, IMT-Lille Douai \& Yncréa-HEI, Laboratoire Génie Civil \& géo-Environnement (ULR 4515), Technoparc \\ Futura, F-62400 Béthune, France
}

\begin{abstract}
This study deals with a numerical investigation to assess and compare the thermal and economic performance of two solar tower power systems. It concerns the Molten Salt (MS) and Direct Steam Generation (DSG) technologies used as heat carrier and storage. For this purpose, a 50 MWe solar tower plant without thermal energy storage under the climatic conditions of the eastern Moroccan region is simulated with the System Advisor Model (SAM) software. The meteorological data has been collected via a high precision meteorological station located in Oujda city $\left(34^{\circ} 40^{\prime} 53^{\prime \prime} \mathrm{N} 1^{\circ} 54^{\prime} 30.9^{\prime \prime} \mathrm{W}\right)$. The results are presented in terms of monthly energy production, annual energy output, and Levelized Electricity Cost (LEC). From these findings, it can be concluded that, for an amount annual Direct Normal Irradiance (DNI) of $1989.9 \mathrm{kWh} / \mathrm{m}^{2} / \mathrm{yr}$, the molten salt plant has the highest annual energy production than the DSG (86.3 GWh for MS against 83.3 GWh for DSG) and the LEC of the Molten salt plant is $12.5 \%$ lower than the DSG plant. O2020. CBIORE-IJRED. All rights reserved
\end{abstract}

Keywords: Direct Steam Generation, LEC, Molten salt, Solar thermal power plant, heat transfer fluid.

Article History: Received: 22 nd March 2020; Revised: $7^{\text {th }}$ May 2020; Accepted: $8^{\text {th }}$ May 2020; Available online: $14^{\text {th }}$ May 2020

How to Cite This Article: Ait Lahoussine Ouali, H., Moussaoui, M. A., Mezrhab, A., Naji, H. (2020) Comparative study between direct steam generation and molten salt solar tower plants in the climatic conditions of the eastern Moroccan region. International Journal of Renewable Energy Development, 9(2), 287-294.

https://doi.org/10.14710/ijred.9.2.287-294

\section{Introduction}

Global primary energy consumption remains dominated by fossil fuels. The economic and environmental consequences are increasingly observed. One can cite some of these consequences: rising costs linked to rising prices of fossil resources, limited level of energy security, contribution to pollution and climate change, the depletion of resources and environmental concerns related to the increasing $\mathrm{CO}_{2}$-concentrations in the atmosphere. In this context, renewable energies exploitation is more and more crucial (Lahoussine et al., 2017; Guechchati et al., 2012). Among these energies, the solar thermals power systems where the sunlight is concentrated to produce the heat at high temperature level received by a Heat Transfer Fluid (HTF) to produce steam. Then, the steam is converted into mechanical energy in a turbine, and finally produces electricity from a generator. Among the various thermodynamic solar concentrator technologies such as Parabolic trough, linear Fresnel reflector, solar power tower and dish-Stirling systems, the solar tower technology is of a growing interest and investment due to its operating at very high temperatures, of the order of $1000{ }^{\circ} \mathrm{C}$. Furthermore, to avoid the need for power transmission networks, all conversion of solar energy is placed in a single fixed area as a receiver. To attract funds to finance and invest, many experimental and numerical studies have been developed and achieved on solar tower technology. Benammar et al. (2014) presented a mathematical model based on energy analysis, for modeling and simulation of the solar tower power plants performances without energy storage. Note that the solar tower system consists of four main subsystems, viz. the heliostat field, tower, the steam generation and the Rankine cycle. Thermal and thermodynamic models of these subsystems have been developed. Gottschalk et al. (2018) carried out a numerical simulation of solar power plant of 100 MWe in various places in India, Germany and Mediterranean countries. The parameters related to direct costs and installation costs are determined. They

*Corresponding author: amezrhab@yahoo.fr 
were then used as input to the System Advisor Model (SAM) software to perform the parametric simulation. (Xu et al, 2011) modeled a solar power tower plant (Dahan with 1 MWe) from mathematical models. The heliostat and superheater cavity receiver models were developed for all of the working conditions using the modular modeling method. The static and dynamic characteristics of the power plant are then analyzed. They obtained and discussed the variation in power output, steam pressure, steam temperature and steam flow. The mathematical model of the Steam Generation System of Solar two power tower plant with lumped parameter method is developed by Zhang et al. (2019). A transient simulation results of a hybrid solar tower power plant with an open volumetric receiver technology for different cities in China presented by Latzke et al. (2015). The open volumetric receiver uses air as a Heat Transfer Fluid (HTF). The meteorological data from these sites was extracted from the Meteonorm software with a time resolution of one hour. They used the simulation environment MATLAB/Simulink as a numerical tool in their study. The results indicate that the highest solar share of about $15 \%$ is achieved for Alxa Zuoqi in Inner Mongolia while the solar share for Taiyuan city is $6 \%$ lower. Concentrated Solar Power (CSP) technologies are part of the most advanced and rapidly growing renewable energies to face the challenges of climate change and improve durability. In another study, Abbas et al. (2012) conducted a techno-economic evaluation of $100 \mathrm{MW}$ of three CSP technologies, namely a solar tower, a parabolic trough and a dish/stirling for electricity generation located in Tamanrasset (Algeria). The SAM software is used to assess the monthly energy production, annual energy output, levelized cost of energy and the net present value. The findings indicate that the Tamanrasset city is a favorable site yielding a lower Levelized Electricity Cost (LEC) for the three Concentrated Solar Power (CSP) technologies. Moukhtar et al. (2018) studied a solar tower plant with thermal energy storage using the artificial neural network (ANN) technique. Then, their simulation results were compared with those coming from the SAM software to validate the model efficiency. Several comparisons were carried out over different seasons of the year and the results indicate the compatibility between the solar tower with ANN model and SAM outputs. The design and optimization of a 100 MWe solar tower plant with thermal energy storage meant for utility scale applications has been explored by (Praveen, 2019). The author studied the performance of the plant in three different locations in Saudi Arabia, as these sites have an Annual Direct Normal Irradiance (DNI) greater than $5.5 \mathrm{kWh} / \mathrm{m}^{2} /$ day. The results indicate that by optimizing the design of solar tower plants, it is possible to achieve a plant configuration that can offer higher plant efficiency and a capacity factor (CF) and the lowest value of the leveled energy cost (LEC). The analysis shows that Yanbu City may have the highest annual energy value and the lowest LEC. Zhou et al. (2020) have investigated the distribution of temperature and heat loss in the molten salt tank (a mixture of $60 \% \mathrm{NaNO}_{3}$ and 40 $\% \mathrm{KNO}_{3}$ ) for solar thermal power plant. The different results indicate that the rate of decrease in temperature of the molten salt at a liquid level of $1039 \mathrm{~mm}$ was 1.88 times greater than a liquid level of $2040 \mathrm{~mm}$, while the difference in total heat loss was $4.3 \%$. These authors concluded that the operating temperature of the molten salt has a significant effect on temperature distribution and heat loss in the storage tank. A techno-economic aspect of the energy of solar towers and parabolic trough plants in the meteorological conditions of Iran (southern region) was carried out using the SAM software by Hirbodi et al. (2020) by considering four plant capacities of 20,50, 100 and 200 MWe with dry and wet cooling options. The various results showed that solar tower power plant with a dry cooling option and a 100 MWe capacity is the most efficient configuration for such a site.

In Morocco, Lahoussine et al. (2015) presented simulation results of 50 MWe tower plant using an open air volumetric receiver under Moroccan climate. They found an average efficiency of the tower system of about $13.6 \%$ for an annual value of Direct Normal Irradiation (DNI) equal to $1989.9 \mathrm{kWh} / \mathrm{m}^{2} / \mathrm{yr}$. It should be pointed out that all solar-powered towers have multiple mirrors to focus the direct normal irradiation on a receiver mounted at the tower top. Note that, Morocco is extremely dependent on fossil fuel imports. It imports more than $90 \%$ of its energy needs (Ezziyyani et al., 2019). However, Morocco has significant potential in solar energy with more than 3,000 hours of sun per year and $5 \mathrm{kWh} / \mathrm{m}^{2} /$ day in terms of energy received (Richts, 2012). Thereby, concerted efforts were made to reduce energy dependency with the launch of the Moroccan Solar Plan in 2009.The project aimed to produce 2,000 MW of solar energy from solar power in 2020 and 4,560 MW by the end of 2030 , as well as to contribute to international efforts to reduce global warming (Chentouf \& Allouch, (2018)).

The aim of this study is to analyze the technoeconomic performance of electric power plants using the CSP technology based on solar tower plants to perform a comparison and to select the best technology on two configurations (Molten Salt and Direct Steam Generation) in the same conditions (nominal capacity, solar multiple, wet cooling system and without Thermal Energy Storage(TES) under the climatic conditions of the Oujda city to fix the highest net production energy and the lowest Levelized Electricity Cost (LEC) of each system. Based on the simulation results from the SAM software, it can be stated that the best configuration is which uses molten salt as heat transfer fluid (mixture of $40 \%$ potassium nitrate $\left(\mathrm{KNO}_{3}\right)$ and $60 \%$ sodium nitrate $\left.\left(\mathrm{NaNO}_{3}\right)\right)$.

\section{Solar tower technology}

A solar tower, depicted in Figure 1, involves hundreds of thousands of mirrors called heliostats with a two-axis control system. These mirrors are orientable and allow the reflection of solar radiation on a receiver located at the top of the tower for a high concentration temperature of the order of $800{ }^{\circ} \mathrm{C}$ to $1000{ }^{\circ} \mathrm{C}$. The receiver is designed to effectively stop concentrated sunlight and absorb it as high temperature heat. Such energy is received by a heat transfer fluid and stored as thermal energy, which is used either to drive an electric generator or heat treatment. It should be noted that the high concentration collection and the high temperature that results from the accumulated heat are of interest for many applications (Yogev et al., 1998). The most common heat transfer fluids in solar towers are air, water/ steam and molten salts. 

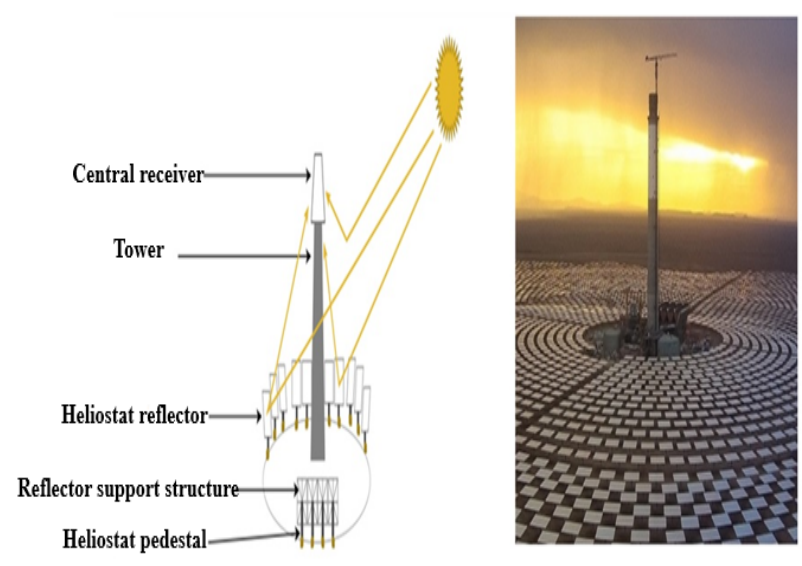

Fig. 1 Sketch of a solar tower and Nour III solar tower plant in Morocco (Blanco et al., 2017)

\subsection{Molten salt systems}

One of the advantages of solar towers is to be able to couple the solar energy concentration system to the heat storage system. As molten salts (mainly composed of sodium nitrate and potassium nitrate $\left(60 \%\right.$ : $\mathrm{NaNO}_{3}$ and $40 \%$ : $\left.\mathrm{KNO}_{3}\right)$ ) form an economical storage fluid adapted to the temperature of the Rankine cycle, they are often used as heat transfer fluid and as thermal energy storage. The fluid is pumped into a cold tank whose temperature is slightly above that of solidification of the salt, then it is heated in the tower by the solar receiver before being stored in a hot tank to be used in a system of heat exchanger to generate steam. The temperature exchanged by the salts can reach $560^{\circ} \mathrm{C}$. Among the solar towers that use molten salts as a HTF, there are Noor III (Morocco), Crescent Dunes (United States) and Gemasolar (Spain).

\subsection{Steam generation systems}

Direct Steam Generation (DSG) was considered in tower installations from the late 1970s (Heller, 2017). This technology integrates concentrated solar energy into a conventional steam cycle, the solar receiver serving as a steam generator. In a few minutes, the steam storage acts as a buffer between capture and energy consumption. Note that superheated steam tower installations have the advantage of being able to use more turbines to prevent condensation of steam, making their operation easier and less expensive to maintain. However, the main difficulty of such installations lies in the thermomechanical constraints (evaporation and overheating) of the absorber tubes which affect the receiver life. Among the solar tower plants using water as HTF, we can cite PS 10 and PS 20 (Spain), Dahan (China), and Sierra Sun Tower and Ivanpah (USA) (Venkatesh et al., 2015).

\section{Methodology}

\subsection{Site geographical location}

The proposed photovoltaic plants using molten salt technology or DSG are located near the Oujda city in Morocco Northeast. This city is at $34.68^{\circ}$ north latitude and $-1.9^{\circ}$ longitude $\left(34^{\circ} 40^{\prime} 53^{\prime \prime} \mathrm{N} 1^{\circ} 54^{\prime} 30.9^{\prime \prime} \mathrm{W}\right)$. It should be noted that Oujda had a population of over 490,000 in 2014.
One year of meteorological data (8760 hours) has been collected via a high-precision meteorological station (SOLYS 2) installed at the University of Oujda, which is composed by a several components such as:

- The direct Normal Irradiance (DNI) in $\mathrm{W} / \mathrm{m}^{2}$ measured with K\&Z CHP1 Pyrheliometer.

- The Global Horizontal Irradiance (GHI) in $\mathrm{W} / \mathrm{m}^{2}$, measured with K\&Z CMP21 Pyranometer.

- The Diffuse Horizontal Irradiance (DHI) in $\mathrm{W} / \mathrm{m}^{2}$ measured with Kipp \& Zonen CMP 11 with shading ball both.

- Pressure sensors.

- The Ambient Temperature in ${ }^{\circ} \mathrm{C}$, measured with Campbell CS215.

- $\quad$ The relative humidity from Campbell CS215.

- The wind speed in $\mathrm{m} / \mathrm{s}$, measured with NRG $40 \mathrm{H}$ Anemometer.

- $\quad$ The wind direction in ${ }^{\circ} \mathrm{N}$ (to East), measured with NRG 200 wind Direction Sensor.

Then, a file TMY3 (DNI, GHI, DHI, wind speed and ambient temperature, etc.) has been used as input data for the SAM software to perform the targeted simulation.

The monthly Direct Normal Irradiation (DNI) for a typical year of the Oujda site is shown in Figure 2. From the figure, it is obvious that the highest DNI of the year is always between $10 \mathrm{am}$ and $2 \mathrm{pm}$. The maximum is reached in almost all months of the year (except March and November) with more than $950 \mathrm{~W} / \mathrm{m}^{2}$. According to the 2012 weather file, the daily average of DNI is $5.45 \mathrm{kWh} /$ $\mathrm{m}^{2}$ / day while the annual average is $1989.9 \mathrm{kWh} / \mathrm{m}^{2} / \mathrm{yr}$ in Oujda. Note that Spain and the United States are the two countries where the CSPs use is the most widespread. Table 1 gathers the annual DNI values of sites in Morocco compared to some sites in Spain and the United States. It is noted that Morocco has favourable conditions for commercial CSP installations.

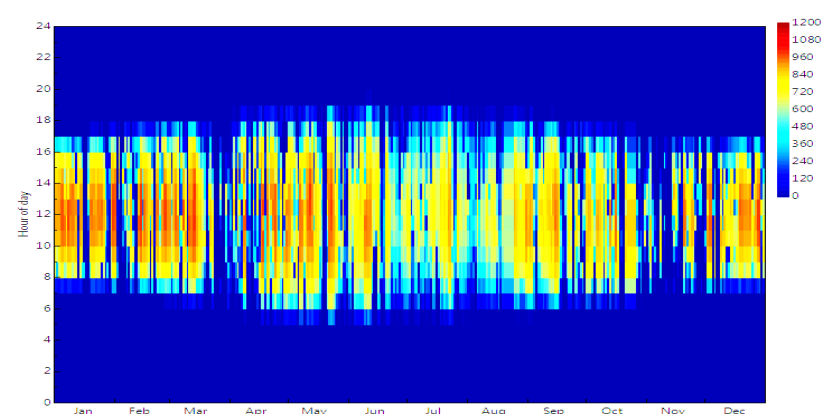

Fig. 2 DNI thermal map in Oujda, Morocco

Table 1

Geographic coordinates and solar conditions of selected locations

\begin{tabular}{|c|c|c|c|}
\hline Location & Laltitude & Longitude & $\begin{array}{l}\text { Annual DNI } \\
{\left[\mathrm{kWh} / \mathrm{m}^{2} / \mathrm{yr}\right]}\end{array}$ \\
\hline Oujda (Morocco) & $34.68^{\circ} \mathrm{N}$ & $-1.9^{\circ} \mathrm{E}$ & 1990 [9] \\
\hline $\begin{array}{l}\text { Ouarzazate } \\
\text { (Morocco) }\end{array}$ & $31.03^{\circ} \mathrm{N}$ & $-6.89^{\circ} \mathrm{E}$ & 2420 \\
\hline Almeria (Spain) & $36.85^{\circ} \mathrm{N}$ & $-2.38^{\circ} \mathrm{E}$ & 2090 [17] \\
\hline Seville (Spain) & $37.42^{\circ} \mathrm{N}$ & $-5.9^{\circ} \mathrm{E}$ & 2074 [18] \\
\hline $\begin{array}{ll}\text { San } & \text { Fransisco } \\
\text { (USA) } & \end{array}$ & $37.61^{\circ} \mathrm{N}$ & $-122.38^{\circ} \mathrm{E}$ & 1880 \\
\hline $\begin{array}{l}\text { Dagget, California } \\
\text { (USA) }\end{array}$ & $34.86^{\circ} \mathrm{N}$ & $-116.78^{\circ} \mathrm{E}$ & 2790 \\
\hline
\end{tabular}


The average monthly values of the ambient temperature at Oujda are presented in Figure 3. It is clearly observed that the maximum average value (of the order of $38^{\circ} \mathrm{C}$ ) of the ambient temperature is reached in August (at noon). However, in February, the maximum reach the value of $12{ }^{\circ} \mathrm{C}$, and the mean annual temperature is $18.3{ }^{\circ} \mathrm{C}$. The analysis shows that the climatic conditions of the Oujda region characterizes a semi-arid climate corresponding to a hot and dry summer and a very cold winter.

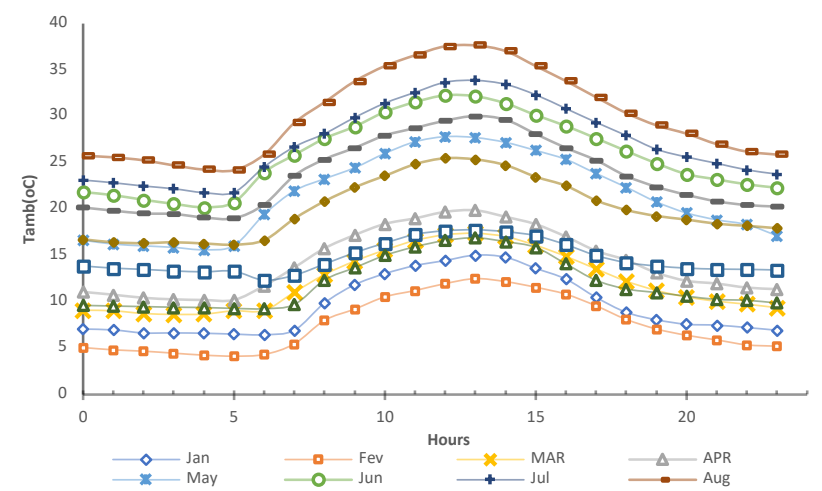

Fig. 3 Monthly values of the ambient temperature in Oujda, Morocco

\subsection{System Advisor Model software}

In our study, the SAM software has been employed to simulate and analyze the two configurations of solar. Note that such software has been developed by the National Laboratory of Renewable Energies (NREL) in collaboration with Sandia National Laboratories (NREL, 2013). Its development consists in studying the technical performance and economic evaluation of different renewable energy systems, such as CSP systems, PV systems and biomass systems based on hourly meteorological data in a specific location. The SAM performance models are based, for each numerical simulation, on the TRNSYS code (Dobos et al., 2013; Fares et al., 2018).

Concerning the solar tower technology, the model simulation equations involve, mainly the equations based on the energy balance, the physical and mechanical phenomena of the different subsystems of the power plant (Neises et al., 2012). It should be noted that the SAM software models have been validated by NREL and presented in detail by Wagner et al. (2011).

\subsection{Economic assessment}

The LEC factor (metric) is one of the key parameter of economic evaluations to compare different power plants, particularly in CSP technology. It represents a compromise between energy production and capital expenditure. In other terms, it measures the total costs over the energy yield. It should be noted that, the LEC value depends on the investment, operating and maintenance (O\&M) costs, which can vary depending on the country and the development level of the technique. Such a factor can be calculated via the following relationship (Sharma et al., 2018; Pitz-Paal et al., 2007; Dersch et al, 2004; NREL., 2013):

$$
L E C=\frac{f \cdot C_{i n v}+C_{O \& M}+C_{f u e l}}{E_{a, e l}}
$$

Where $E_{a, e l}$ is the annual electricity production (kWh), $C_{i n V}$ is the investment cost, Co\&M is the annual operation and maintenance cost, $C_{\text {fuel }}$ is the fuel price, and $f$ is the annuity factor, which is calculated via the following relationship:

$$
f=\frac{K_{d}\left(1+K_{d}\right)^{n}}{\left(1+K_{d}\right)^{n}-1}+K_{\text {ins }}
$$

With $n$ is the plant life, $K_{d}$ is the interest rate, and $K_{\text {ins }}$ is the annual insurance rate.

Note that the different categories of direct costs are:

- Direct costs: A cost of site improvements, A cost of the Heliostat field, A cost of the electrical equipment of the power plant indirect costs.

- An indirect cost is one that cannot be identified with a piece of equipment or an installation service. Two types of indirect cost are defined by the SAM software: the costs of study and management and total land costs.

\section{Parameters of the proposed plants}

Table 2 shows the technical parameters included in the SAM software to achieve the simulations for both configurations (MS and DSG). Recall that this software, developed by the NREL, is considered as one of the most powerful software for CSP systems. It has been used by many researchers to simulate hourly performances (thermal and financial) of CSP plants (Denholm et al., 2015; Batainehet al., 2018; Wagner et al., 2012; Guzmanet al., 2014; Blair et al., 2008). It combines an hourly simulation model with performance, cost and financing models to compute energy production costs and cash flows. Note that the towers' heights are identical.

Table 2

Parameters of the molten salt and DSG tower plants

\begin{tabular}{lcc}
\hline Parameters & $\begin{array}{c}\text { Molten } \\
\text { salt }\end{array}$ & DSG \\
\hline HTF type & Salt & Water/Steam \\
Heliostat area & 144 & 139.68 \\
Number of heliostats & 2435 & 2492 \\
water usage per wash $\left(\mathrm{L} / \mathrm{m}^{2}\right)$ & 0.7 & 0.7 \\
receiver height & $14.22 \mathrm{~m}$ & $20.27 \mathrm{~m}$ \\
tower height & $150 \mathrm{~m}$ & $150 \mathrm{~m}$ \\
Receiver type & Externa & Direct Steam \\
& $\mathrm{l}$ & \\
& &
\end{tabular}

\section{Result and Discussion}

Figure 4 presents the structure of the molten salt treatment plants and DSG towers. To provide $50 \mathrm{MWe}$ of net power without thermal storage under the conditions 
considered, 2435 heliostats (respectively 2492) seem necessary for the molten salt tower (respectively for the DSG tower). To optimize the heliostats field design and calculate the optimal number of heliostats per zone, the field is set as a number of heliostats per radial zone, as indicated in the field diagram. The field was divided into 144 zones (12 radial zones x 12 azimuthal zones). Table 3 yields the optimal number of heliostats per zone for the both configuration plants.

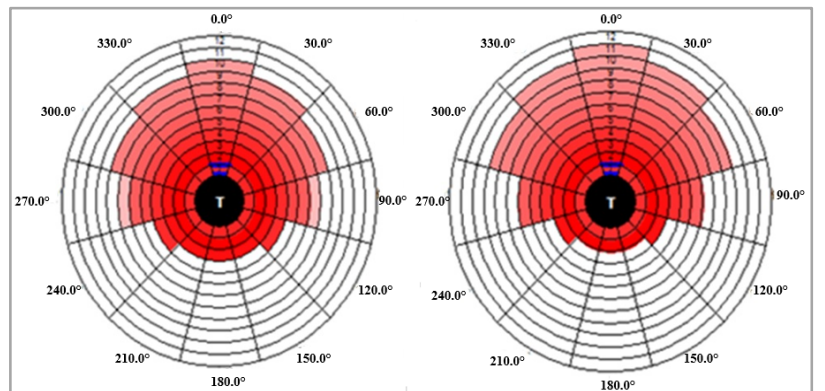

(a)

(b)

Fig. 4 Layout of molten salt tower plant (a) and DSG plant (b)

Table 3a

The optimal number of heliostats per zone of the molten salt plant

\begin{tabular}{lllllllllllll}
\hline & $\mathbf{0 . 0}$ & $\mathbf{3 0 . 0}$ & $\mathbf{6 0 . 0}$ & $\mathbf{9 0 . 0}$ & $\mathbf{1 2 0 . 0}$ & $\mathbf{1 5 0 . 0}$ & $\mathbf{1 8 0 . 0}$ & $\mathbf{2 1 0 . 0}$ & $\mathbf{2 4 0 . 0}$ & $\mathbf{2 7 0 . 0}$ & $\mathbf{3 0 0 . 0}$ & $\mathbf{3 3 0}$ \\
\hline Rad.1 & 10 & 10 & 10 & 10 & 10 & 10 & 10 & 10 & 10 & 10 & 10 & 10 \\
Rad.2 & 28 & 28 & 28 & 28 & 28 & 28 & 28 & 28 & 28 & 28 & 28 & 28 \\
Rad.3 & 35 & 35 & 35 & 35 & 35 & 35 & 35 & 35 & 35 & 35 & 35 & 35 \\
Rad.4 & 39 & 39 & 39 & 39 & 39 & 0 & 0 & 0 & 39 & 39 & 39 & 39 \\
Rad.5 & 41 & 41 & 41 & 41 & 0 & 0 & 0 & 0 & 0 & 41 & 41 & 41 \\
Rad.6 & 42 & 42 & 42 & 42 & 0 & 0 & 0 & 0 & 0 & 42 & 42 & 42 \\
Rad.7 & 42 & 42 & 42 & 20 & 0 & 0 & 0 & 0 & 0 & 20 & 42 & 42 \\
Rad.8 & 42 & 42 & 42 & 0 & 0 & 0 & 0 & 0 & 0 & 0 & 42 & 42 \\
Rad.9 & 42 & 42 & 0 & 0 & 0 & 0 & 0 & 0 & 0 & 0 & 0 & 42 \\
Rad.10 & 41 & 0 & 0 & 0 & 0 & 0 & 0 & 0 & 0 & 0 & 0 & 0 \\
Rad.11 & 0 & 0 & 0 & 0 & 0 & 0 & 0 & 0 & 0 & 0 & 0 & 0 \\
Rad.12 & 0 & 0 & 0 & 0 & 0 & 0 & 0 & 0 & 0 & 0 & 0 & 0
\end{tabular}

Table 3b

The optimal number of heliostats per zone of DSG solar tower plant

\begin{tabular}{lllllllllllll}
\hline & $\mathbf{0 . 0}$ & $\mathbf{3 0 . 0}$ & $\mathbf{6 0 . 0}$ & $\mathbf{9 0 . 0}$ & $\mathbf{1 2 0 . 0}$ & $\mathbf{1 5 0 . 0}$ & $\mathbf{1 8 0 . 0}$ & $\mathbf{2 1 0 . 0}$ & $\mathbf{2 4 0 . 0}$ & $\mathbf{2 7 0 . 0}$ & $\mathbf{3 0 0 . 0}$ & $\mathbf{3 3 0}$ \\
\hline Rad.1 & 10 & 10 & 10 & 10 & 10 & 10 & 10 & 10 & 10 & 10 & 10 & 10 \\
Rad.2 & 29 & 29 & 29 & 29 & 29 & 29 & 29 & 29 & 29 & 29 & 29 & 29 \\
Rad.3 & 36 & 36 & 36 & 36 & 36 & 0 & 0 & 0 & 36 & 36 & 36 & 36 \\
Rad.4 & 40 & 40 & 40 & 40 & 0 & 0 & 0 & 0 & 0 & 40 & 40 & 40 \\
Rad.5 & 43 & 43 & 43 & 43 & 0 & 0 & 0 & 0 & 0 & 43 & 43 & 43 \\
Rad.6 & 43 & 43 & 43 & 43 & 0 & 0 & 0 & 0 & 0 & 43 & 43 & 43 \\
Rad.7 & 44 & 44 & 44 & 0 & 0 & 0 & 0 & 0 & 0 & 0 & 44 & 44 \\
Rad.8 & 43 & 43 & 43 & 0 & 0 & 0 & 0 & 0 & 0 & 0 & 43 & 43 \\
Rad.9 & 43 & 43 & 43 & 0 & 0 & 0 & 0 & 0 & 0 & 0 & 43 & 43 \\
Rad.10 & 42 & 42 & 0 & 0 & 0 & 0 & 0 & 0 & 0 & 0 & 0 & 42 \\
Rad.11 & 42 & 0 & 0 & 0 & 0 & 0 & 0 & 0 & 0 & 0 & 0 & 0 \\
Rad.12 & 0 & 0 & 0 & 0 & 0 & 0 & 0 & 0 & 0 & 0 & 0 & 0
\end{tabular}

Figure 5 depicts the net electric energy output for molten salt and DSG solar tower plants of the selected site. The amount of net electric power produced by the proposed plants has the same tendency with regard to the evolution of solar radiation (proportional to DNI). The best productions are in May, June and July. Such a figure clearly shows that the molten salt plant produces the largest energy volume. The output of the DSG tower plant peaked in May (10.2 GWh), compared to a production output of $2.3 \mathrm{GWh}$ in November. For the molten salt tower, maximum production is $10.9 \mathrm{GWh}$ in May, $6 \%$ higher than the DSG plant for the same month. Regarding the minimum (of the order of $2.86 \mathrm{GWh}$ ), it is obtained in November and February, respectively. Thereby, as expected, production peaks in summer due to strong sunshine in the region, while production decreases in 
Citation: Ait Lahoussine Ouali, H., Moussaoui, M. A., Mezrhab, A., Naji, H. (2020) Comparative study between direct steam generation and molten salt solar tower plants in the climatic conditions of the eastern Moroccan region. Int. Journal of Renewable Energy Development, 9(2), 287-294, doi: 10.14710/ijred.9.2.287-294

P a g e 1292

winter and autumn, solar radiation being lower than that in summer. Figure 6 presents the cost contribution on the real LEC of molten salt and DSG configurations without thermal storage. It can be seen that the project cost consists mainly of the power plant cost and heliostats for both configurations, while the tower represents $4 \%$ of the investment costs for both configurations.

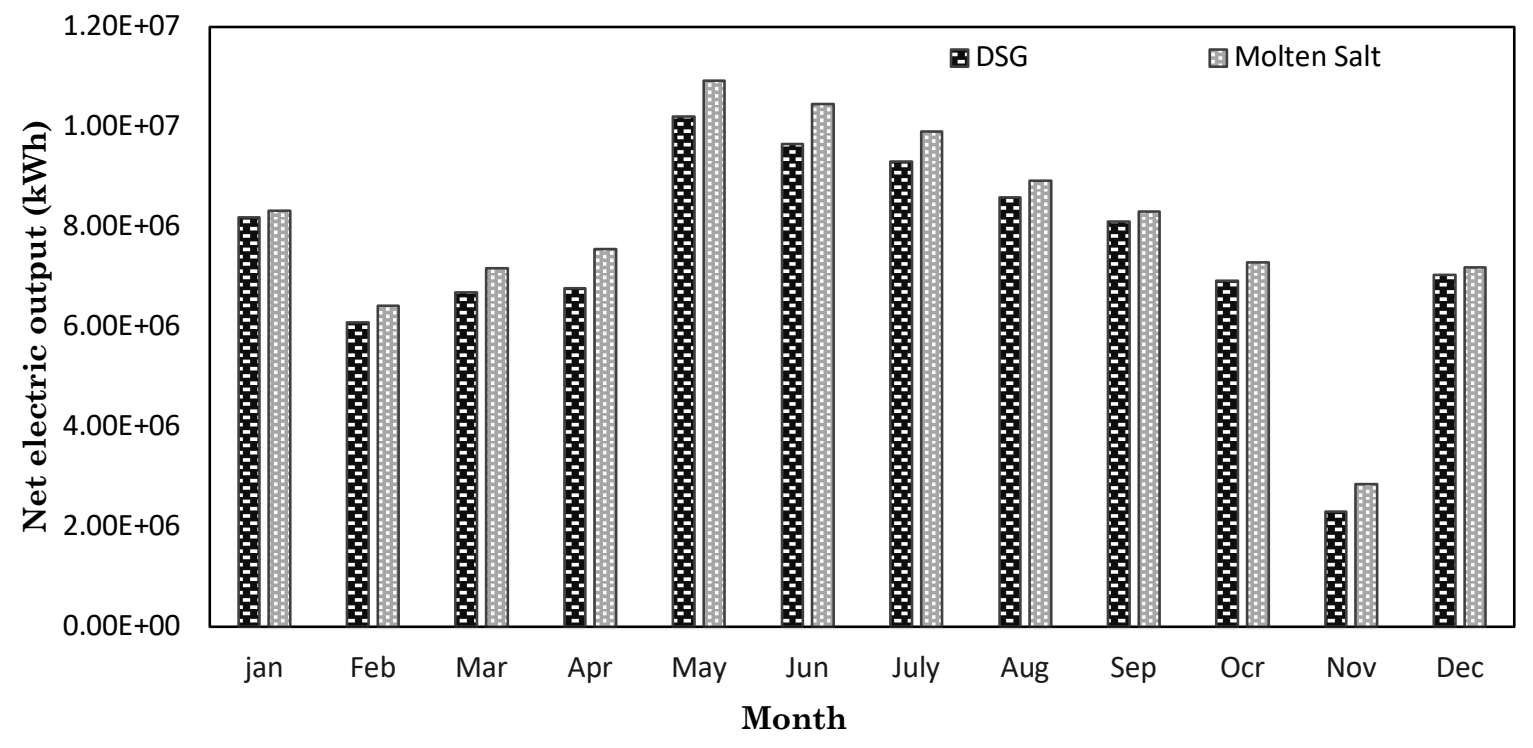

Fig. 5 Net electricity production for both systems vs. months

Table 4

Cost assumptions for proposed plants

\begin{tabular}{|c|c|c|c|}
\hline & Molten Salt & DSG & Unit \\
\hline Heliostat field & 180 & 180 & $\mathrm{US} \$ / \mathrm{m}^{2}$ \\
\hline Power block & 850 & 850 & US $\$ / \mathrm{m}^{2}$ \\
\hline Contingency & 7 & 7 & $\%$ \\
\hline Total installed cost & 256 & 273 & Million \$ \\
\hline EPC (\% of direct cost) & 11 & 11 & $\%$ \\
\hline $\begin{array}{l}\text { Estimated Total installed cost per } \\
\text { O\&M costs }\end{array}$ & 5085 & 5467 & $\$ / \mathrm{kW}$ \\
\hline Fixed & 65 & 65 & $\$ / \mathrm{kW}-\mathrm{yr}$ \\
\hline Variable & 3 & 3 & \$/MW.h \\
\hline Real LEC & 0.24 & 0.27 & $\$ / \mathrm{kWh}$ \\
\hline
\end{tabular}

Table 5

Summary of simulation results

\begin{tabular}{lcc}
\hline & Molten salt & DSG \\
\hline Annual energy (GWh) & 86.3 & 83.3 \\
Total land area (acres) & 428 & 433 \\
Direct cost (US\$) & 219403553 & 234155033 \\
Indirect cost (US\$) & 37191553 & 39453225 \\
Total project cost (US\$) & 256594968 & 303938688 \\
LEC (US $\$ / k W h)$ & 0.24 & 0.27 \\
Capacity factor $(\%)$ & 20.7 & 19.7 \\
\hline
\end{tabular}



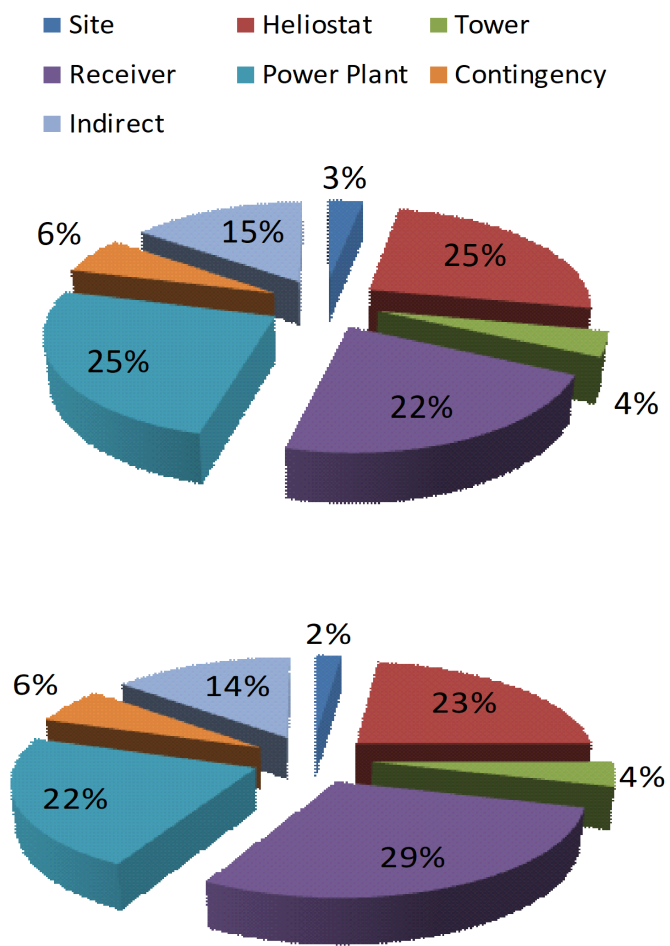

Fig. 6 Relative cost contribution of each project for proposed Molten salt (top) and DSG solar tower plants (bottom)

Cost assumptions, financial parameters and data enabling to perform simulations via the SAM software are presented in Table 4 for the two solar towers configurations. Cost simulation ultimately predicted capital and power generation costs for two systems with different technical characteristics. It appears that the LEC value of the molten salt plant is $12.5 \%$ lower than that of the DSG plant, the efficient molten salt system producing more annual energy seems more interesting.

Some other annual performance parameters of the both solar power plant like the Capacity Factor(CF) and annual is gathered in Table 5 for the selected site (for the amount annual DNI of $1989.9 \mathrm{kWh} / \mathrm{m}^{2} / \mathrm{yr}$ and the mean annual temperature is $18.3^{\circ} \mathrm{C}$ ). Note that the capacity factor is the ratio of the system's predicted electrical output in the first year of operation to the nameplate output. In our case, the capacity factor for molten salt is higher than DSG (20.7\% instead of $19.7 \%$ ), the annual net electricity production is $86.3 \mathrm{GWh}$ for the molten salt treatment plant instead of $83.3 \mathrm{GWh}$ for the DSG. Regarding the total cost of the project, we notice that the DSG plant is $15 \%$ higher than the MS plant. These results (50 MW without thermal energy storage) clearly indicate that the best technology in the climatic conditions of the Oujda city (Morocco) should be a molten salt solar power plant.

\section{Conclusion}

An in-depth comparison of thermal performance and economic efficiency between solar energy technologies of two power plant configurations was performed under the climate of Oujda in Morocco Northeast using the SAM software. The results show that, for 50 MWe without thermal storage, the molten salt plant has the highest energy production than the DSG (86.3 GWh against 83.3 GWh for DSG) and that the Levelized Electricity Cost of the Molten salt plant is $12.5 \%$ lower than the DSG plant. These results point out that the best technology under the climatic conditions of Eastern Moroccan region is a molten salt solar power plant.

From the results, thereby obtained, it could be stated that they could be used over the future development of concentrated solar power plants in the Morocco eastern region.Indeed, any government or decision-makers need to anticipate the specific inputs or costs (direct and indirect) of projects as well as their outputs or benefits before any decision to set up. Consequently, it seems necessary to have a simulation tool such as SAM software to predict the performance of solar plants. Finally, it turns out that the installation of solar tower power plants in eastern Morocco is very beneficial for the country's economy and could significantly reduce its energy imports.

$\begin{array}{ll}\text { Abbreviations } \\ \text { CF } & \text { Capacity Factor } \\ \text { CSP } & \text { Concentrating Solar Power } \\ \text { DHI } & \text { Diffuse Horizontal Irradiance } \\ \text { DNI } & \text { Direct Normal Irradiation } \\ \text { DSG } & \text { Direct Steam Generation } \\ \text { GHI } & \text { Global Horizontal Irradiance } \\ \text { HTF } & \text { Heat Transfer Fluid } \\ \text { LEC } & \text { Levelized Electricity Cost } \\ \text { MS } & \text { Molten Salt } \\ \text { NREL } & \text { National Renewable Energy Laboratory } \\ \text { O\&M } & \text { Operation and Maintenance } \\ \text { SAM } & \text { System Advisor Model } \\ \text { TES } & \text { Thermal Energy Storage }\end{array}$

\section{References}

Abbas, M., and Merzouk, N. K., (2012), Techno economic study of solar thermal power plants for centralized electricity generation in Algeria, 2nd Int. Symposium on Environment Friendly Energies and Applications, IEEE, Newcastle upon Tyne, UK, 25-27 June. https://doi.org/10.1109/EFEA.2012.6294067.

Ait Lahoussine Ouali, H., Guechchati, R., Moussaoui, M. A., and Mezrhab, A. (2017). Performance of parabolic through solar power plant Under Weather conditions of the Oujda city in Morocco, Appl. Sol. Energy, 53(1), 45-52. https://doi.org/10.3103/S0003701X17010121.

Ait Lahoussine Ouali, H., Merrouni, A.A., Moussoaui, M. A., and Mezrhab, A., (2015), Electricity yield analysis of a $50 \mathrm{MW}$ solar tower plant under Moroccan climate, 1st Int. Conference on Electrical and Information Technologies ICEIT, IEEE, Marrakech, Morocco, 25-27 March. https://doi.org/10.1109/EITech.2015.7162978.

Bataineh, K. M., and Gharaibeh, A., (2018), Optimization Analyses of Parabolic Trough (CSP) Plants for the Desert Regions of the Middle East and North Africa (MENA), Jordan J. Mech. Ind. Eng., vol. 12 (1), 33- 43.

Benammar, S., Khellaf, A., and Mohammedi, K. (2014), Contribution to the modeling and simulation of solar power tower plants using energy analysis, Energy Convers. Manag., $78, \quad 923-930$. https://doi.org/10.1016/j.egypro.2014.10.203

Ben Fares, M. S., \& Abderafi, S. (2018). Water consumption analysis of Moroccan concentrating solar power station. Solar Energy, 172, 146-151. https://doi.org/10.1016/j.solener.2018.06.003 
Citation: Ait Lahoussine Ouali, H., Moussaoui, M. A., Mezrhab, A., Naji, H. (2020) Comparative study between direct steam generation and molten salt solar tower plants in the climatic conditions of the eastern Moroccan region. Int. Journal of Renewable Energy Development, 9(2), 287-294, doi: 10.14710/ijred.9.2.287-294

$\mathrm{P}$ a g e 1294

Blair, N., Mehos, M., and Christensen, C., (2008), Sensitivity of concentrating solar power trough performance, cost and financing with solar advisor model, 14th Biennial CSP Solar PACES Symposium, 4-7 March, Las Vegas, Nevada, USA.

Blanco, M. J., and Miller, S., (2017), Introduction to concentrating solar thermal (CST) technologies, Advances in Concentrating Solar Thermal Research and Technology, 325. https://doi.org/10.1016/B978-0-08-100516-3.00001-0

Chentouf, M., and Allouch, M., (2018), Renewable and Alternative Energy Deployment in Morocco and Recent Developments in the National Electricity Sector, MOJ Solar Photoen Sys, 2(1): $\quad$ 00017, https://doi.org/00017, 10.15406/oajp.2018.02.00017

Denholm, P., Y-H. Wana, Y-H., Hummona, M., and Mehos, M. (2014), The value of CSP with thermal energy storage in the western United States, Energy Proc., 49, 1622-1631. https://doi.org/10.1016/j.egypro.2014.03.171

Dersch, J., Geyer, M., Herrmann, U., Jones, S. A., Kelly, B., Kistner, R., Ortmanns, W., Pitz-Paal, R., and Henry Price, (2004). Trough Integration into Power Plants-a Study on the Performance and Economy of Integrated Solar Combined Cycle Systems. Energy, 29, 947-959. https://doi.org/10.1016/S0360-5442(03)00199-3.

Dobos, A., Neises, T., Wagner, M., (2014), Advances in CSP simulation technology in the System Advisor Model. Energy Procedia 49, 2482-2489. https://doi.org/10.1016/j.egypro.2014.03.263

Ezziyyani, M, Hamdache, A., Ezziyyani, M., and L. Cherrat, L., (2019). Impacts of Climate Change on the Production, Yield and Cost of Adaptation of Varieties Imported from Strawberry Plants in the Perimeter of Loukkos (Morocco), Int. Conf. on Advanced Intelligent Systems for Sustainable Development, AI2SD'2018, 911, 37-45. https://doi.org/10.1007/978-3-030-11878-5_4.

Gottschalk, A., and Ramamoorthi, U., (2018). Parametric Simulation and Economic Estimation of Thermal Energy Storage in Solar Power Tower, Materials Today: Proceedings, 5, 1571-1577.

Guechchati, R., Moussaoui, M. A., and Mezrhab A. (2012) Improving energy efficient envelope design for Moroccan houses, Int. J. Ambient Energy, 33(4), 184-192. https://doi.org/10.1080/01430750.2012.686199

Guzman, L., Henao, A., and Vasquez, R., (2014), Simulation and optimization of a parabolic trough solar power plant in the city of Barranquilla by using system advisor model (SAM), Energy Procedia, 57, 497-506.

Heller, P., (2017), The Performance of Concentrated Solar Power (CSP) Systems, Modelling, Measurement and Assessment, ISBN 9780081004470, Woodhead Publishing.

Hirbodi, K., Enjavi-Arsanjani, M., \& Yaghoubi, M. (2020). Techno-economic assessment and environmental impact of concentrating solar power plants in Iran. Renewable and Sustainable Energy Reviews, 120, 109642 https://doi.org/10.1016/j.rser.2019.109642.

Latzke, M, Alexoupoulos, S., Kronhardt, V., Rendón, C., and Sattler, J., (2015), Comparison of potential sites in China for erecting a hybrid solar tower power plant with air receiver, Energy Proc., 69, 1327-1334. https://doi.org/10.1016/j.egypro.2015.03.142.

Moreno-Tejera, S., Silva-Pérez, M.A., Lillo-Bravo, I., and Ramírez-Santigosa, L., (2016), Solar resource assessment in Seville, Spain. Statistical characterization of solar radiation at different time resolutions, Sol. Energy, 132, 430-441. https://doi.org/10.1016/j.solener.2016.03.032

Moser, M., Pecchi, M., and Fend, T., 2019, Techno-economic assessment of solar hydrogen production by means of thermo-chemical cycles, Energies, 12, 352. https://doi.org/10.3390/en12030352

National Renewable Energy Laboratory, 2013, Simple Levelized Cost of Energy (LCOE) Calculator, http://www.nrel.gov/analysis/.

Moukhtar, I., A. Elbaset, A., Z. El Dein, A., Qudaih, Y., Blagin, E., Uglanov, D., \& Mitani, Y. (2018). Electric power regulation and modeling of a central tower receiver power plant based on artificial neural network technique. Journal of Renewable and Sustainable Energy. https://doi.org/10.1063/1.5029898

Neises, T., \& Wagner, M. J. (2012). Simulation of Direct Steam Power Tower Concentrated Solar Plant. ASME 2012 6th Int. Conference on Energy Sustainability.

Pitz-Paal, R. et al., (2007), Development Steps for Parabolic Trough Solar Power Technologies with Maximum Impact on Cost Reduction, J. Sol. Energy Eng., 129, 371-377. https://doi.org/10.1115/1.2769697.

Praveen R.P, (2019). Performance Analysis and Optimization of Central Receiver Solar Thermal Power Plants for Utility Scale Power Generation. Sustainability, 12(1), 127. https://doi.org/10.3390/su12010127.

Richts, C., (2012), The Moroccan solar plan. A comparative analysis of CSP and PV utilization until 2020. M.Sc. degree, University of Kassel, Germany.

Sharma, C., Sharma, A.K., Mullick, S.C., and Kandpal, T.C., (2018), Cost reduction potential of parabolic trough based concentrating solar power plants in India, Energy Sustain. Dev., 42, 121-128. https://doi.org/10.1016/j.esd.2017.10.003

Srilakshmi, G., Venkatesh, V., Thirumalai, N.C., and Suresh, N.S., (2015), Challenges and opportunities for Solar Tower technology in India, Renew. Sust. Energy Rev., 45, 698-709. https://doi.org/10.1016/j.rser.2015.02.016

Wagner, M. J., \& Gilman, P. (2011). Technical manual for the SAM physical trough model (No. NREL/TP-5500-51825). National Renewable Energy Lab. (NREL), Golden, CO (United States).

Wagner, M.J., and Zhu, G., (2012), A direct-steam linear Fresnel performance model for NREL's system advisor model, ESFuelCell2012-91317. Proceedings of the ASME, 6th Int. Conf. on Energy Sustainability \& 10th Fuel Cell Science, Engineering and Technology Conf., San Diego, 23-26 July.

Xu, E., Yu, Q., Wang, Z., and Yang, C., (2011), Modeling and simulation of $1 \mathrm{MW}$ DAHAN solar thermal power tower plant, Renew. Energy, 36, 848-857. https://doi.org/10.1016/j.renene.2010.08.010

Yogev, A., Kribus, A., Epstein, M., and Kogan, A., (1998), Solar "tower reflector" systems: a new approach for hightemperature solar plants, Int. J. Hydrogen Energy, 23.4, 239-245. https://doi.org/10.1016/S0360-3199(97)00059-1

Zhang, Q., Wang, Z., Du, X., Yu, G., and Wu, H., (2019), Dynamic simulation of steam generation system in solar tower power plant, Renew. Energy, 135, 866-876. https://doi.org/10.1016/j.renene.2018.12.064

Zhou, H., Shi, H., Zhu, Y., \& Fang, W. (2020). An experimental investigation of temperature distribution and heat loss in molten salt tanks in concentrating solar power plants. Journal of Renewable and Sustainable Energy, 12(1), 014101. https://doi.org/10.1063/1.5131071. 